\title{
Development Of Adaptive, Spritual, Academic And Social (ASAS) Programs In Revitalizing Social Interactions Of Students
}

\author{
Elvri Simbolon', Roida Lumbantobing ${ }^{1}$, Jupalman Simbolon', Harisan Boni Firmando ${ }^{2}$ \\ ${ }^{1}$ Sosial Humaniora \\ ${ }^{2}$ Institut Agama Kristen Negeri Tarutung \\ E-mail address simbolon.elvri@iakntarutung.ac.id ; E-mail address \\ tobing.roida@iakntarutung.ac.id ;E-mail address simbolon.jupalman@iakntarutung.ac.id ; E-mail \\ address boni.harisan@iakntarutung.ac.id ;
}

\begin{abstract}
If the diversity of a community is not managed properly, it will cause various problems that can lead to disharmony in the interaction patterns in that community. The diversity of students of the Faculty of Social Science and Christian Humaniora (FISHK) of IAKN Tarutung leads to a tendency to cause grouping and even create competition, which greatly affects the patterns of interactions among students. The purpose of this research is to develop the ASAS programs in revitalizing the social interaction patterns of students of the Faculty of Social Science and Christian Humaniora (FISHK) of IAKN Tarutung. This research method uses a quantitative description, which aims to explain events that are described in the form of Figures containing useful numbers. The four indicators for the Adaptive Program (A) show that $31.13 \%$ of respondents strongly agree to hold adaptive programs, $61.13 \%$ of respondents agree, $6.78 \%$ disagree, and $0.88 \%$ of respondents strongly disagree. The seven indicators for the Spiritual Program (S) show that 38.14\% of respondents strongly agree to hold spiritual activities, $56.71 \%$ of respondents agree, $5.14 \%$ of respondents disagree, and no one strongly disagrees. The five indicators for the Academic Program (A) show that $29.4 \%$ of respondents strongly agree to hold an academic program, $61.6 \%$ of the respondents agree, $8.4 \%$ of respondents disagree, and $0.6 \%$ of the respondents strongly disagree. The four indicators for the Spiritual Program (S) show that $30.75 \%$ of respondents strongly agree to hold social activities, $60 \%$ of the respondents agree, $8.75 \%$ of respondents disagree, and less than one percent $(0.5 \%)$ of respondents strongly disagree. From all the indicators in the ASAS program that have been implemented, it can be concluded that the ASAS (Adaptive, Spiritual, Academic and Social) programs can be as solutions in revitalizing interaction patterns among students and those can become references for readers or others in overcoming disharmony issues in a community.
\end{abstract}

Keywords: Adaptive, Spiritual, Academic, Social, Revitalizing Interaction Patterns

\section{INTRODUCTION}

The general form of social process is social interaction because social interaction is the main condition for the occurrence of social activities.

Humans interact with each other in life to create social life in a social group. Such life will only occur when humans, in this case, individuals or groups of people, work together, talk to each other to achieve common goals. 
Each individual or group in society has characters, thoughts, habits, and emotions that are not the same as each other. These differences will be carried and become the basis for a person or group to have social interaction in society. These differences also often cause problems and conflicts in the social interaction process in a group or community organization, which certainly can change the order of life in a community group. In their daily lives, many people are faced with a large and varied social world, and to help make sense of this heterogeneity, people often view themselves and others in terms of group membership (Nezlek J. V., 2007)

Social interaction is also closely related to and influenced by the identity and role of a person or group in society. Awareness of identities and knowledge of the roles of each of these identities are useful principles for establishing good social interactions in a society.

Social interactions range between success and failure. What makes the difference? The most successful interactions have the following ingredients: people are bodily assembled so that they can read tacit messages in all modalities; they create a mutual focus of attention, the intersubjective awareness of focusing on the same thing; they build up a shared mood or emotion. All the ingredients feedback into each other, intensifying the focus and the mood, and turning it into rhythmic entrainment among all present bodies and their nervous systems. This would be a good description of fans during an exciting moment in a game; Durkheim applied it to political crowds and religious raptures; Goffman (1967), as well as conversational analysis, gave close observations (including voice recordings) that show how these ingredients of social solidarity can be found in the smallest social encounters (Collins, 2016).

If the diversity that exists in a community is not managed properly, it will cause various problems that can cause disharmony in the interaction patterns in such a community. There are many ways to prevent this disharmony, such as increasing tolerance, increasing a sense of belonging, and enforcing justice or establishing programs that can increase teamwork. Students of the Faculty of Social Sciences and Christian Humaniora (FISHK) of the IAKN Tarutung are quite diverse in terms of ethnicities, origins, place of residence, welfares. There is a tendency to create groups and even have competitions to greatly affect the interaction patterns among students. The interaction patterns that can be observed is the establishment of friendship groups and intensive interactions in the lecture hall and outside the lecture room with those of the same ethnicity, dormitories, fellow scholarship recipients, or fellow hometowns. In other words, the more differences, the less interaction. These things cause unhealthy competition and jealousy among students. If there is no further action on these problems, it may lead to bigger conflicts.

\section{LITERATURE REVIEW}

In this case, conflicts and social problems that occur in social interactions among students in this faculty are divided into two (2) major parts. The first is a conflict or social problems due to things that are inherent and carried within students, such as ethnic differences, different backgrounds, and regional origins (Clinciu, 2013). This often leads to ethnocentrism among students, who think that their friends are only those of the same ethnicity, as well as groupings because, on the basis of similarities and differences in their area of residence, there are also student groupings based on their entry paths to this faculty. These groupings can be found in several activities in the faculty, both academic and nonacademic activities, and can be more clearly observed in the process of socializing and interacting among students. The second is a conflict or social problems caused by things that are inherent or acquired by students after they enter and take courses at this faculty, such as differences in study programs, differences in housing (living in dormitories and outside dormitories), and also differences in style. Life and personal facilities they have as well as differences in attitudes and actions between seniors and juniors (Helena J.M. Pennings, (2018)). 
Conflicts or problems that arise because of the things mentioned above have bad influences on student interaction, so that it greatly affects the academic atmosphere and intercourse among students, such as groups (gangs) that are accidental but eventually formed naturally due to differences which are difficult to accept and unite. Lack of cohesiveness between students with other students from different study programs, lack of cohesiveness between students living in the dormitory and outside the dormitory, senior authoritarian attitudes towards juniors, and many other social interaction problems are feared will have a negative impact on student social life and also adversely affects the academic situation in such faculty.

The implementation of a program specifically designed for a particular community often has a positive impact on that community, such as there is an interactive influence between the competence of peer partners and the competence of people who use AAC so that it affects each other.(Lilienfeld \& Erna, 2005). In addition, implementing a program can also help participants learn from each other and teach and share life experiences. (Gamliel \& Nadav, Knowledge Exchange, Social Interaction and Empowerment in an Intergenerational Technology Program at School, 2014).

The researchers offer a program called the ASAS (Adaptive, Spiritual, Academic, and Social) programs as solutions in revitalizing interaction patterns among students, and those can become references for readers or others in overcoming disharmony issues in a community.

This program is designed by holding various kinds of activities that are applied to students outside of lecture activities. scientists are calling for calls for multi-cultural engagement to be part of the formal and informal curricula of today's universities(Fozdar \& Volet, 2015)

First, the adaptive program aims to foster adaptive attitudes in order to improve students' adaptability to their environment by carrying out activities that involve all students. Secondly, spiritual programs aim to increase religious knowledge, which will later affect the moral and ethical formation of students in interaction. Thirdly, academic programs are non-lecture programs that aim to explore the potentials, knowledge, creativity, and skills of students that can increase the spirit of solidarity, cohesiveness, cooperation, and sportsmanship. The last program, which is a social program involving all students in social activities and also in service to other fellow students, the environment, and the surrounding community, so as to create a sense of mutual care and solidarity as well as good cooperation among students. Learning to recognize differences and to respect and engage in the mediated space are good qualities to possess in a multicultural world (Li, 2015, pp. 237-254)

The implementation of the ASAS program was carried out for one semester with 64 students as research samples for each research indicator. Most respondents gave feedbacks that they agreed and even strongly agreed to implement the ASAS program.

Judging from the findings of this research, it is recommended that it needs to be applied permanently on campus and in other organizations in order to revitalize interaction patterns that tend to cause divisions within the organization.

\section{RESEARCH METHODOLOGY}

A descriptive exploratory qualitative design was used for this study. Interviews and focus groups were utilized to obtain rich, thick, descriptive data indicative of the experiences participants. (Rashida, Ruth, Andrea, \& Tahirah, 2019).

The population in this research were all students at the Faculty of Social Sciences and Christian Humaniora, with a sample of 64 people who represented a variety of economic backgrounds, ethnicity, residence, and scholarship recipients and who were not scholarship recipients. The instrument in the form of a questionnaire was arranged based on the indicators of implementing the ASAS program that 
had been designed by the researchers. Questionnaires with a Likert scale of 46 items were distributed to 64 respondents via a google form. Each respondent's feedback was analyzed and described based on the percentage of the respondents' feedback who strongly agree, agree, disagree, and strongly disagree (José M. Mestre, 2006. supl., pp. 112-117).

\section{FINDING AND DISCUSSION}

Implementation of the Adaptive, Spiritual, Academic, and Social (ASA) program in this research is affected by several indicators. Each indicator is analyzed based on the percentage of responses provided by respondents.

Several research findings are as follows:

\section{IV.1 Adaptive Program (A)}

a. Sports Activities or Fun Games

During one semester, sports programs involving all students were held every weekend, and fun games are held once a month. At the end of the semester, students were requested to provide feedback in relation to those activities. Respondents' feedbacks are shown inFigure 1 below:

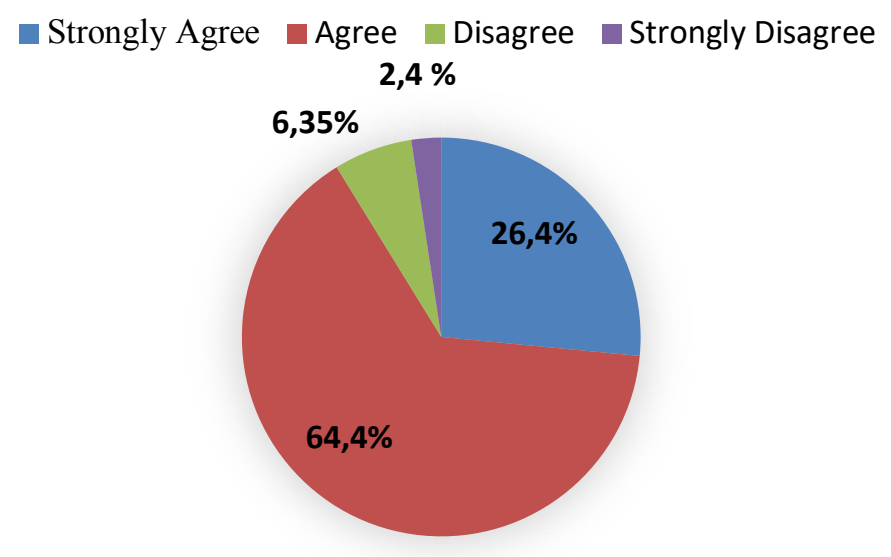

Figure 1. Percentage of the Respondents' Feedback on the implementation of Sports Activities and Fun Game at FISHK

\section{b. Campus Clean-Up Activities}

Mutual cooperation activities in terms of cleanliness and arrangement of the environment and parks in campus location were done once a week by involving the whole students both inside and outside the dormitory for one semester. At the end of the semester, students were requested to provide feedback, as shown in Figure 2 below: 


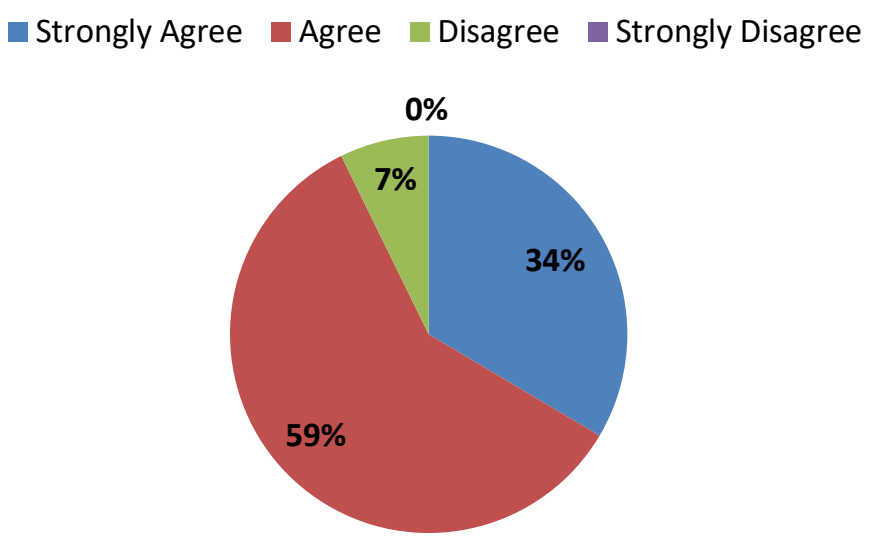

Figure 2. Percentage of the Respondents' Feedback on the implementation of Campus Clean-Up Activities

\section{c. Campus Team Activities}

Campus team activities include forming groups of worshipers and groups for other activities that involve all students, which were carried out by turns. Those activities were carried out during one semester intensively. At the end of the semester, students were requested to provide feedback in relation to such activities. Respondents' feedbacks are shown in Figure 3 below:

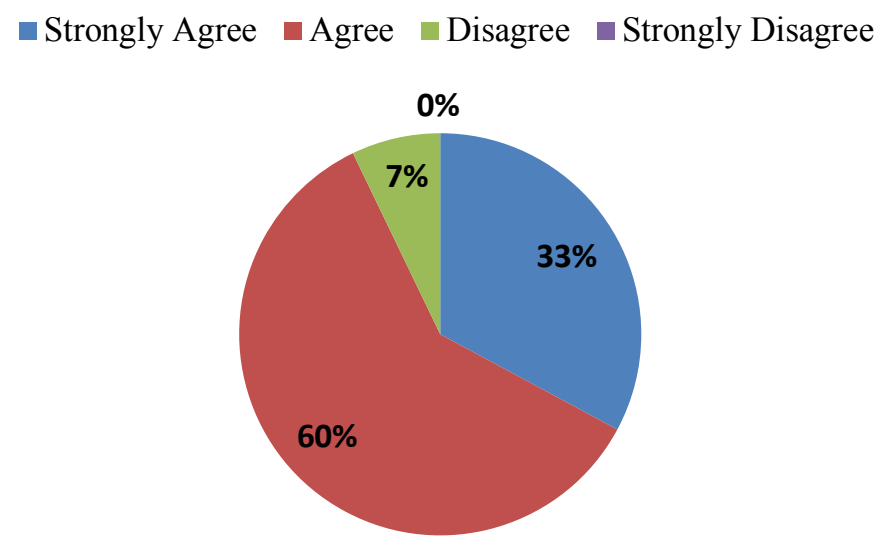

Figure 3. Percentage of the Respondents' Feedback on the implementation of Campus Team Activities

\section{IV.2 Spiritual Program}

a. Campus Spiritual Discussion

Religious (spiritual) discussion activities in groups and also with the coach or seniors as well as with academic advisors were carried out every two weeks for one semester. 
At the end of such discussion, students were requested to provide feedback in relation to such activities, as shown in Figure 4 below:

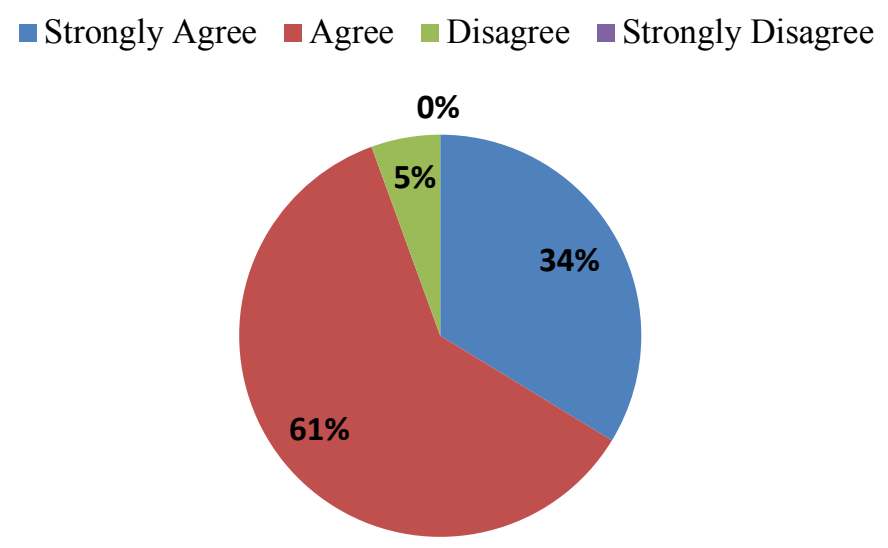

Figure 4. Percentage of the Respondents' Feedbacks on the Implementation of Campus Spiritual Discussion

\section{b. Early Sunday Service}

The early Sunday service is an activity held regularly at the beginning week by involving students as alternating worshipers and involving all existing study programs. At the end of the semester, students were requested to provide feedback, as shown in Figure 5 below:

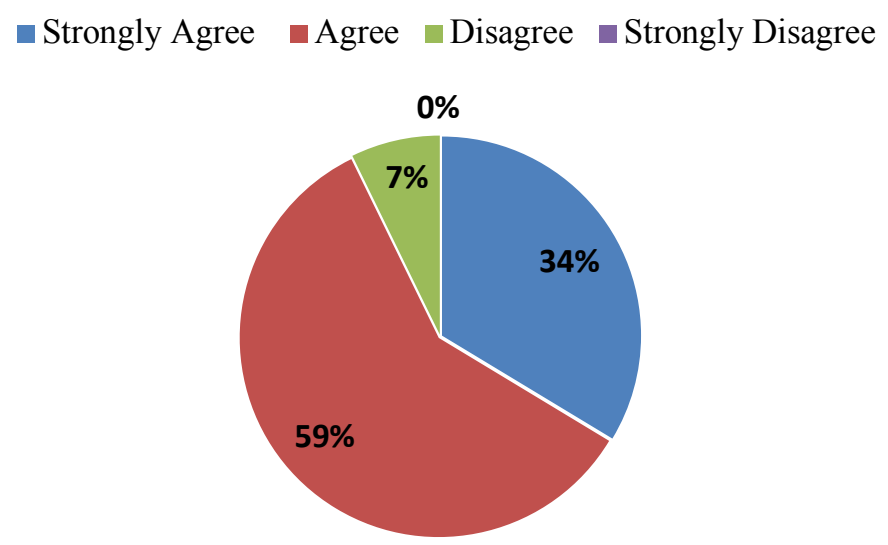

Figure 5. Percentage of Respondents' Feedback on the Implementation of Early Sunday

c. Dorm Service.

\section{Service}

Dormitory service is a devotional activity which is held in the morning and evening every day and is held in Campus Dormitory 1, which is fully occupied by students of the Faculty of Social Sciences and Christian Humaniora. At the end of the semester, 
students were requested to provide feedback. Respondents' feedbacks are as shown in Figure 6 below:

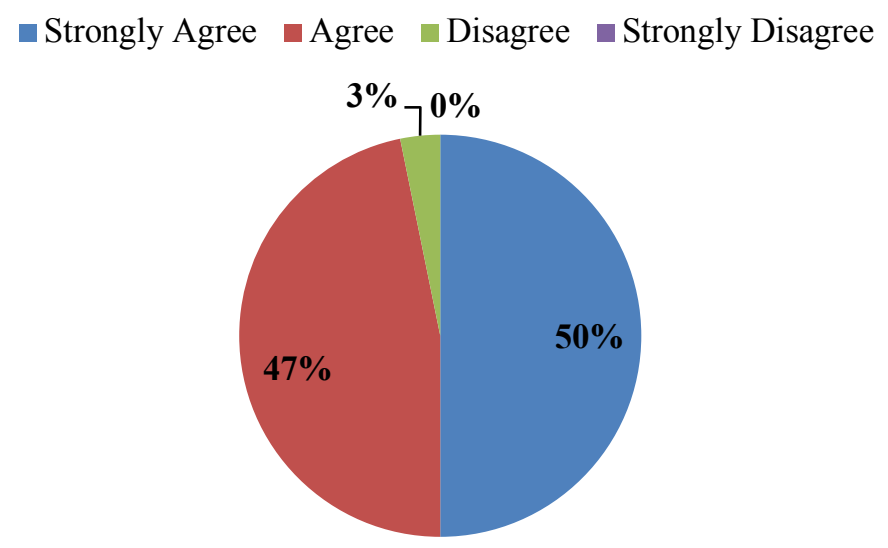

Figure 6. Percentage of the Respondents' Feedback on the Implementation of the Dorm Service

\section{d. Worship Activities Carried Out in the Classroom}

Worship activities were carried out in the classroom every morning before the lecture activities. At the end of the semester, students were requested to provide feedback, as shown in Figure 7 below:

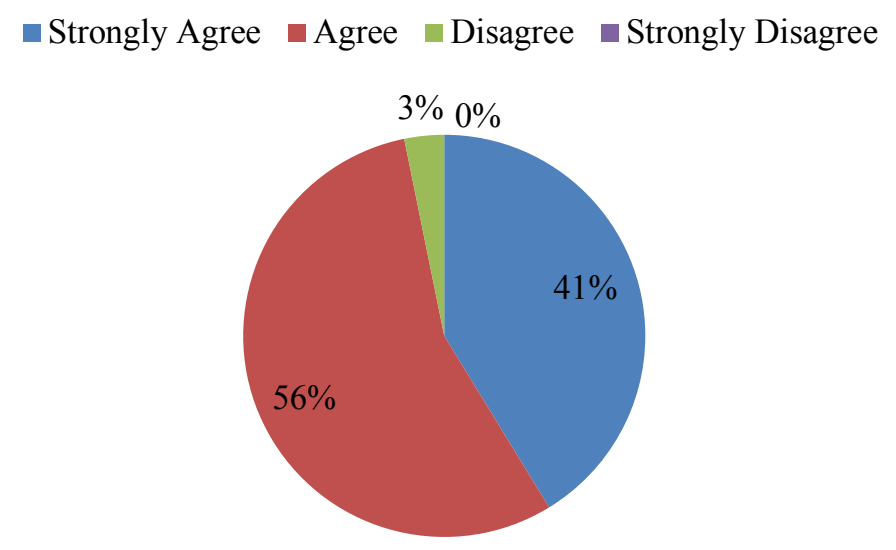

Figure 7. Percentage of the Respondents' Feedback on the Implementation of Worship Activities Carried Out in the Classroom

\section{e. Pray in Turns}

Prayer activities that take turns by students at the end of each lecture. At the end of the semester, respondents were requested to provide feedback, as shown in Figure 8 below: 


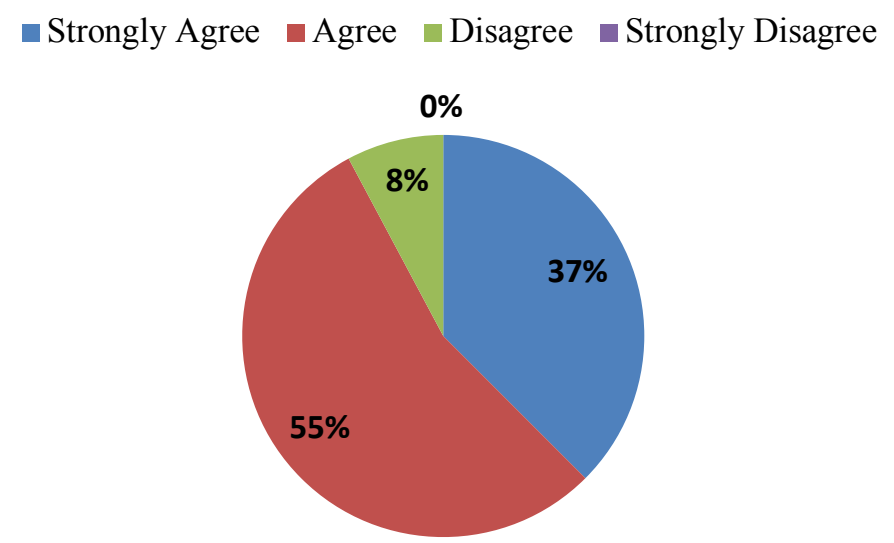

Figure 8. Percentage of the Respondents' Feedback on the Implementation of Pray in Turns Activities

\section{f. Saturday Night Service}

Spiritual services were carried out on Saturday night by visiting the church and joining church youths according to the denominational background of each student. Respondents were requested to provide feedback, as shown in Figure 9 below:

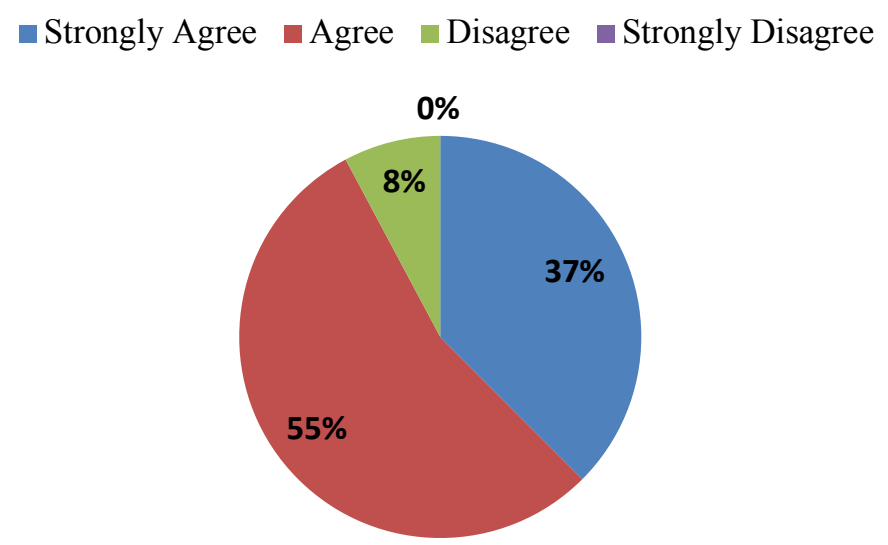

Figure 9. Percentage of the Respondents' Feedback on the Implementation of the Saturday Night Service Activities

\section{g. Compulsory Worship}

This activity requires every faculty-student, especially those living in the dormitory, to worship every week in the church according to the denomination of each student. The respondents' feedback in relation to this activity is as shown in Figure 10 below: 


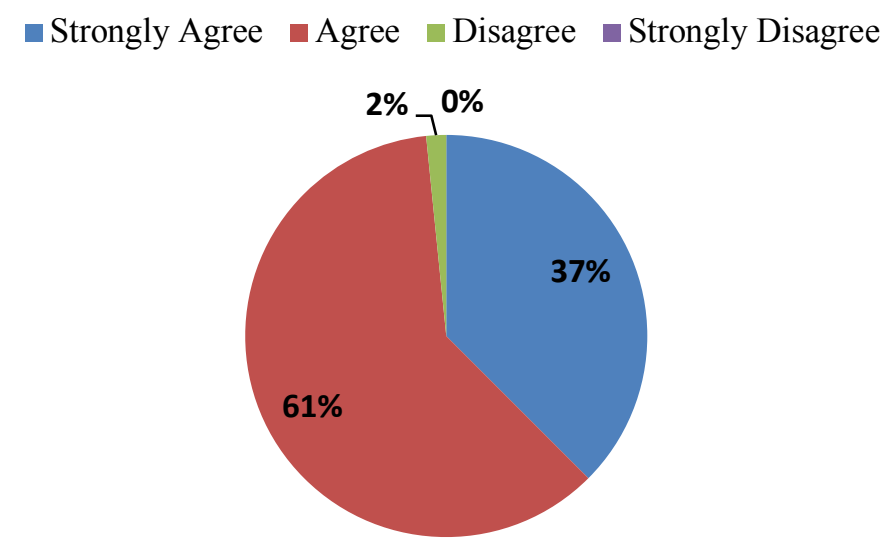

Figure 10. Percentage of the Respondents Feedback of the Implementation of the Compulsory Worship Activities

\section{IV.3 Academic Program (A)}

a. Study Together

Study together activities are also known as study groups or discussion groups. During one semester, students were formed into study groups combining junior and senior students. At the end of the semester, respondents were requested to provide feedback, as shown in Figure 11 below:

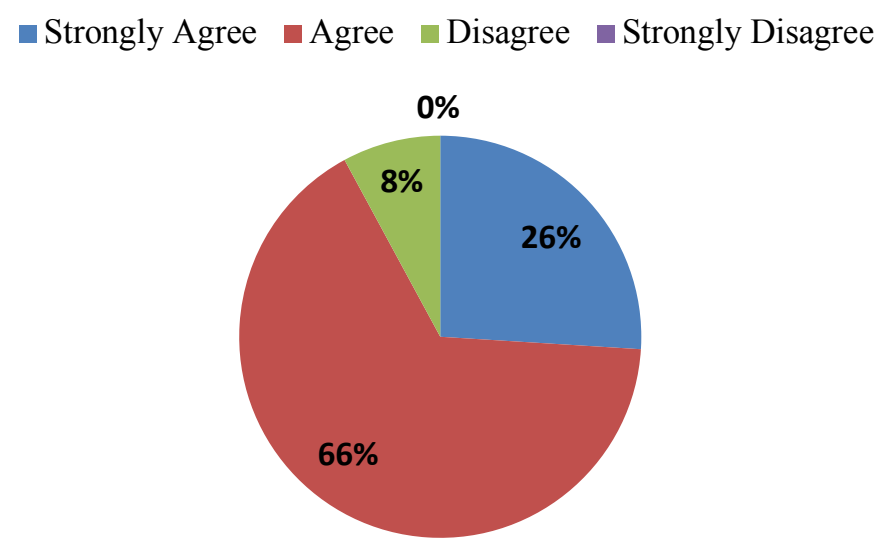

Figure 11. Percentage of the Respondents' Feedback on the Implementation of the Study Together Activities

\section{b. Meeting with the Academic Advisor (PA)}

The academic program is maximized even more with efforts to guide each student in relation to academic achievement by the Academic Advisor (PA). This activity was carried out every two (2) weeks for one semester. The respondents' feedbacks in relation to this activity are shown in Figure 12 below: 
$\square$ Strongly Agree $\square$ Agree $\square$ Disagree $\square$ Strongly Disagree

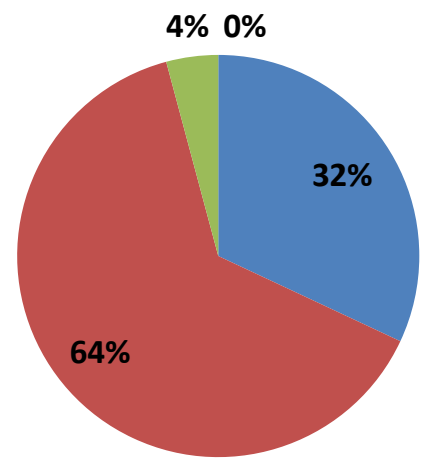

Figure 12. Percentage of the Respondents' Feedback in relation to the Meeting with the Academic Advisor

\section{c. Off-Campus Assignments}

Off-Campus Assignments means activities in the form of assignments by lecturers that require students to explore information and experiences outside the campus or by mingling directly with the community. The respondents' feedback in relation to these activities are shown in Figure 13 below:

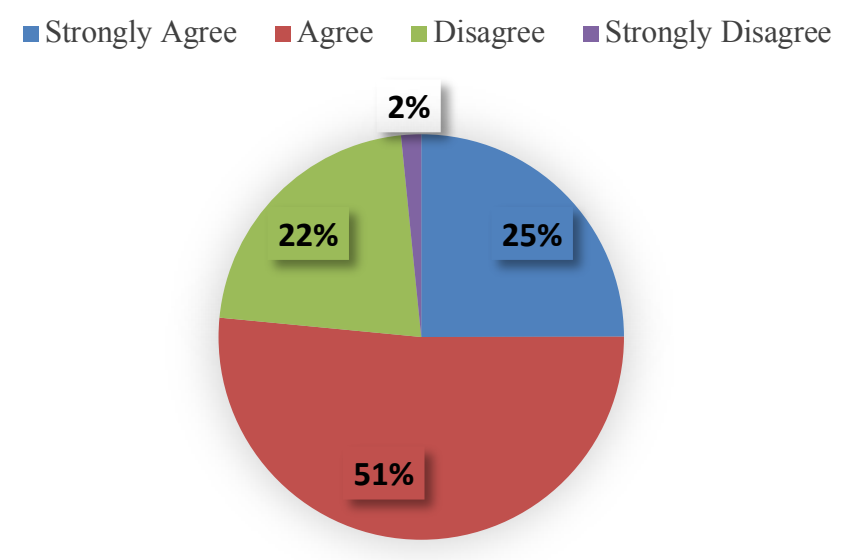

Figure 13. Percentage of the Respondents' Feedback on the Implementation of the Off-Campus Assignments Activities

\section{d. Extracurricular Activities}

Extracurricular activities may be in the form of sports activities, choirs, art studios. Those were in the form of activity units that can be joined by all students. The respondents' feedbacks in relation to those activities are shown in Figure 14 below: 


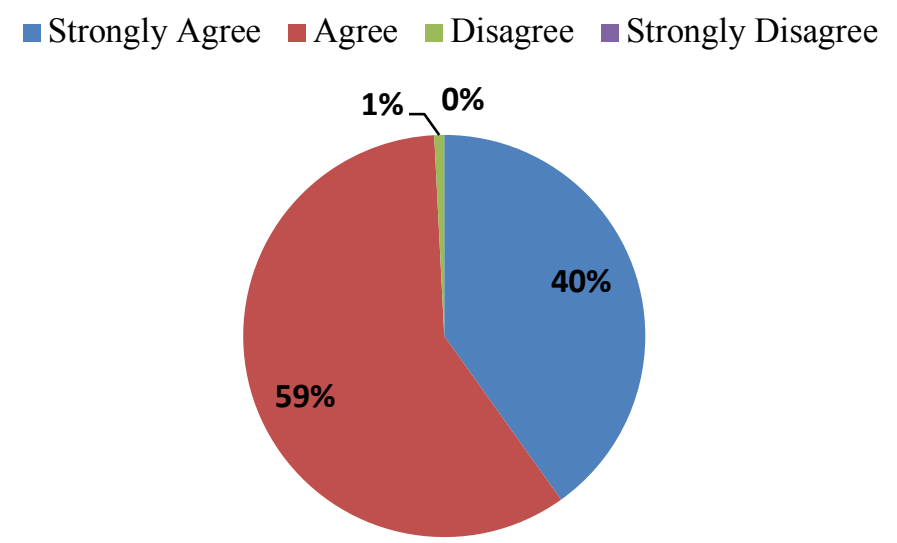

Figure 14. Percentage of the Respondents' Feedback on the Implementation of the Extracurricular Activities

\section{e. Joint Scientific Meetings}

Joint scientific meeting means activities involving students in events and scientific meetings inside or outside the campus. The respondents' feedback in relation to these activities are shown in Figure 15 below:

\section{च Strongly Agree $\quad$ Agree $\square$ Disagree $\square$ Strongly Disagree}

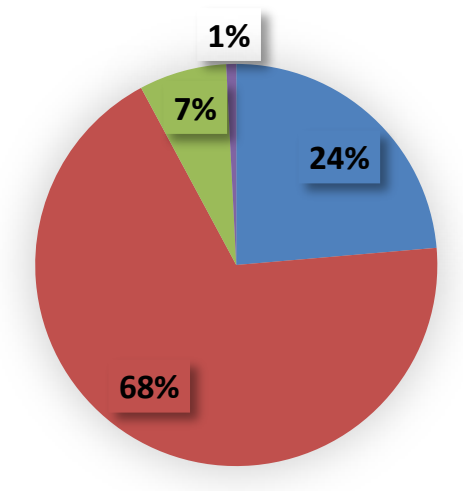

Figure 15. Percentage of the Respondents' Feedback on the Implementation of the Joint Scientific Meetings

\section{IV.4 Social (S)}

a. Social Fundraising

The activity involved the act of voluntary fundraising by all students if any of their friends are unfortunate or sick. This activity has been carried out for one semester. Respondents' feedbacks in relation to this activity are shown in Graph 16 below: 
$\square$ Strongly Agree $\square$ Agree $\square$ Disagree $\square$ Strongly Disagree

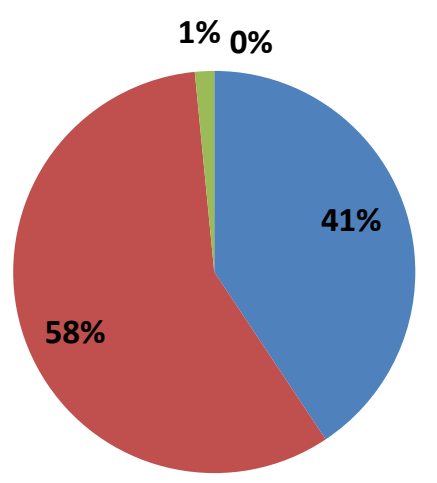

Figure 16. Percentage of the Respondents' Feedback on the Implementation of Social Fundraising

\section{b. Proper Waste Management}

Activities to manage waste properly were carried out on campus and outside the campus. The respondents' feedbacks in relation to this activity are shown in Figure 17 below:

\section{च Strongly Agree $\quad$ Agree $\square$ Disagree $\square$ Strongly Disagree}

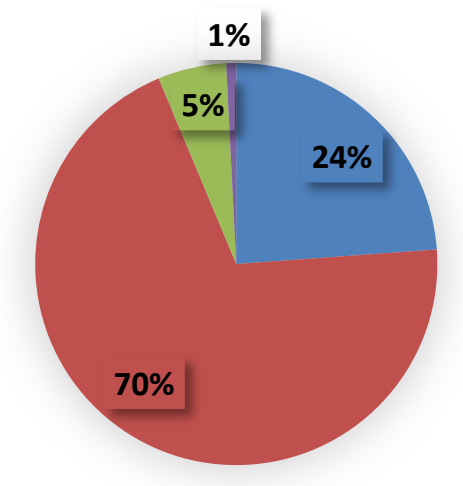

Figure 17. Percentage of the Respondents' Feedback on the Implementation of Proper Waste Management Activities

\section{c. Community Service}

Social service activities are aimed at the community and the environment around the campus where the campus is domiciled. The respondents' feedbacks in relation to this activity are shown in Figure 18 below: 
$\square$ Strongly Agree $\square$ Agree $\square$ Disagree $\square$ Strongly Disagree

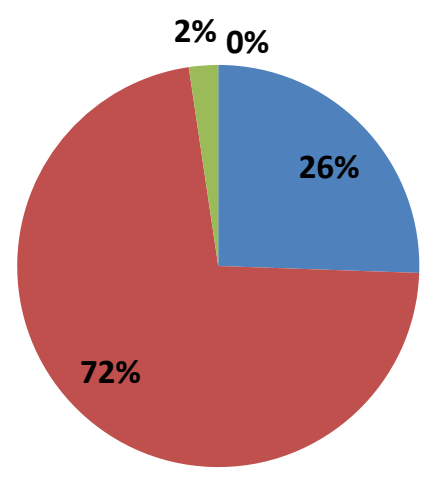

Figure 18. Percentage of the Respondents' Feedback on the Implementation of the Community Services Activities

\section{d. Children Mentoring Activities}

This activity included a voluntary and free mentoring and learning program for children facilitated by students in collaboration with faculty lecturers. The respondents' feedbacks in relation to this activity are shown in Figure 19 below:

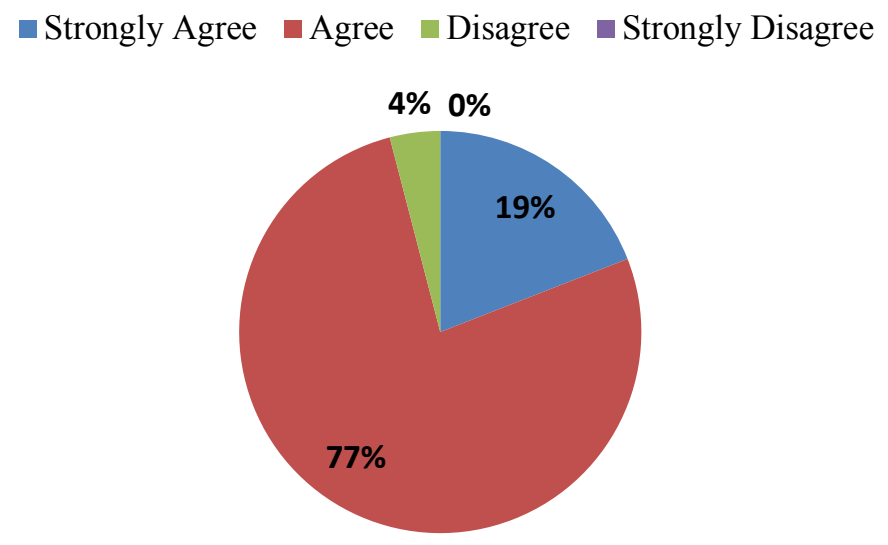

Figure 19. Percentage of the Respondents' Feedback on the Implementation of the Children Mentoring Activities

\section{CONCLUSION AND FURTHER RESEARCH}

Social interaction may occur when two individuals or groups have social contact and communication. Social contact can take three (3) forms, namely between individuals, between individuals and a group, or vice versa, and between a group and another group. Communication allows cooperation between individuals and/or between groups. In addition to that, misunderstanding in communication can also lead to disputes.

Social interaction can be classified into two (2) types, namely associative and dissociative social processes. The associative process includes cooperation, accommodation, assimilation, and 
acculturation, while the dissociative process includes competition, controversy, disputes, and social conflicts.

If the diversity of a community is not managed properly, it will cause various problems that can lead to disharmony in interaction patterns in the community. The diversity of students of the Faculty of Social Science and Christian Humaniora (FISHK) of IAKN Tarutung leads to a tendency to cause grouping and even create competition, which greatly affects the patterns of interactions among students.

The ASAS (Adaptive, Spiritual, Academic, and Social) programs as solutions in revitalizing interaction patterns among students, and those can become references for readers or others in overcoming disharmony issues in a community. In conclusion, the ASAS program has an important influence in shaping student interaction patterns.

\section{REFERENCES}

Aurel Ion Clinciu (2012). Adaptation and Stress for First-Year University Students. Procedia -Social and Behavioral Sciences 78 (2013) $718-722$

Collins, Randall. (, 2016). Micro-sociology of sport: interaction rituals of solidarity, emotional energy, and emotional domination, European Journal for Sport and Society, 2.

Fozdar, F. V. (2015). Cultural Self-Identification and Orientation to Cross-Cultural Mixing on an Australian University. Journal of Intercultural Studies, 51-68.

Gamliel, T., \& Gabay, N. (2014). Knowledge Exchange, Social Interaction, and Empowerment in an intergeneration Technology program at school. Educational Gerontology, 597-617.

Helena J.M. Pennings, Mieke Brekelmans, Pamela Sadler, Luce C.A. Claessens, Anna C. van der Want, Jan van Tartwijk (2018). Interpersonal adaptation in teacher-student interaction. Journal homepage: www.elsevier.com. Learning and Instruction (2018). 41-57

José M. Mestre, Rocío Guil, Paulo N. Lopes, Peter Salovey and Paloma Gil-Olarte (2006). Emotional intelligence and social and academic adaptation to school. Psicothema 2006. Vol. 18, supl., pp. 112-117.

Li, X. (2015). International students in China: Cross-cultural interaction, integration, and identity construction. Journal of language, identity \& education, 237-254.

Lilienfeld, M., \& Erna, A. (2005). The Social interaction of an Adolescent who uses AAC: The Evaluation of a Peer-Training. Augmentative and Alternative Communication, 278-294.

Nezlek, J. V. (2007). Social Identity in Daily Social Interaction. Psychology Press, 243.

Rashida, C. M., Ruth, C. M., Andrea, C., \& Tahirah, M. N. (2019). Getting help: an exploration of student experiences with a campus program addressing basic need insecurity. Journal of Social Distress and The Homeless, 1-9. 